Mehmet Akif Ersoy Üniversitesi Fen Bilimleri Enstitüsü Dergisi 10(1): 102-110 (2019)

The Journal of Graduate School of Natural and Applied Sciences of Mehmet Akif Ersoy University 10(1): 102-110 (2019)

Derleme Makale / Review Paper

\title{
Et Ürünlerinde Enkapsülasyon Teknolojisinin Kullanımı
}

\author{
Ali SOYUÇOK (iD) 1*, Birol KILIÇ iD2, Gülden BAŞYiĞiT KILIÇ ${ }^{(D)}$ \\ ${ }^{1}$ Burdur Mehmet Akif Ersoy Üniversitesi, Bilimsel ve Teknoloji Uygulama ve Araştırma Merkezi, Burdur \\ 2Süleyman Demirel Üniversitesi, Mühendislik Fakültesi, Gıda Mühendisliği Bölümü, Isparta \\ ${ }^{3}$ Burdur Mehmet Akif Ersoy Üniversitesi, Mühendislik Mimarlık Fakültesi, Gıda Mühendisliği Bölümü, Burdur \\ Geliş Tarihi (Received): 21.02.2019, Kabul Tarihi (Accepted): 15.02.2019 \\ $\square$ Sorumlu Yazar (Corresponding author ${ }^{*}$ ): asoyucok@mehmetakif.edu.tr \\ (C) +902482133275 边 +902482133288
}

\section{$\overline{o ̈ z}$}

Gıda bilimi açısından enkapsülasyon teknolojisi gıda bileşenleri, aroma maddeleri, tatlandırıcılar, renklendiriciler, vitaminler, mineraller, enzimler ve mikroorganizmaların bir kaplama materyali kullanılarak farklı teknikler ile kaplanması işlemidir. Bebek mamalarına enkapsüle vitaminlerin ilavesiyle başlayan bu alandaki çalışmalar, balık yağlarının enkapsüle edilerek farklı gıda matrislerinde kullanılmasıyla hız kazanmıştır. Teknolojik, coğrafik ve mikrobiyolojik şartlardaki farklılıklardan dolayı her zaman aynı kalite ve güvenilirlikte et ürünü üretilmesinde sıkıntılar oluşmaktadır. Ayrıca ısı işlem uygulanan ürünlerde laktik asit bakterilerinin inhibe olması, yetersiz tat ve aroma oluşumu gibi bazı kalite kusurlarının ortaya çıkmasına sebep olmaktadır. Bu kapsamda enkapsülasyon teknolojisinin et ürünlerinde kullanılmasıyla fermantasyon işleminin etkinliği artırabilmekte ve spesifik ürün karakteristiği sağlanabilmektedir. Enkapsüle edilmiş kültürler kullanılarak üretilen ısıl işlem görmüş et ürünlerinde işleme sırasında istenilen tat ve aromanın oluştuğu ve depolama süresi boyunca enkapsüle bakteri sayısının stabil olduğu yapılan çalışmalarla kanıtlanmıştır. Ayrıca et ürünlerine ilave edilen esansiyel yağların enkapsülasyonu ile oksidasyon hızı yavaşlatılarak ürünlerin raf ömrünün uzatılabileceği gözlemlenmiştir. Bu çalışmada et ve et ürünlerinde enkapsülasyon teknolojisinin kullanımı hakkında bilgi verilmiştir.

Anahtar Kelimeler: Enkapsülasyon, et ürünleri, antimikrobiyal, antioksidan

\section{Use of Encapsulation Technology in Meat Industry}

\begin{abstract}
Encapsulation technology used in food science area is the process of coating food components, flavors, sweeteners, colorants, vitamins, minerals, enzymes and microorganisms with different techniques using a coating material. Studies in this area started with the addition of encapsulated vitamins to infant formula and accelerated by the use of encapsulated fish oils in different food matrices. Due to the differences in technological, geographic and microbiological conditions, there are always problems in producing meat products with the same quality and reliability. In addition, inhibition of lactic acid bacteria in heat-treated products causes some quality defects such as inadequate taste and aroma formation. Thus, using encapsulation technology in fermentation process increase the efficiency and specific product characteristics development in meat products provided. Studies have shown that heat-treated meat products produced by using encapsulated cultures provided desired taste and flavor, and stable bacteria count during processing and storage of production.
\end{abstract}

Keywords: Encapsulation, meat products, antimicrobial, antioxidant 


\section{Giriş}

Son yıllarda gıdaların işlenmesi ve depolanması sırasında biyoaktif maddelerin stabilitesini korumak ve gidayla istenmeyen etkileşimlerin meydana gelmesini önlemek için enkapsülasyon teknolojisi kullanılmaya başlanmıştır. Enkapsülasyon uygulamaları, üründe raf ömrü boyunca meydana gelen degradasyonu durduğu veya hızını yavaşlattığı için giderek yaygınlaşmaktadır (McClements ve ark., 2009). Bu teknoloji kimya, ziraat, tıp, ilaç gibi pek çok alanda uygulama alanına sahip olup gıda endüstrisinde de kullanımı üzerinde çalışmalar yoğunlaşmıştır. (Champagne ve ark., 2010).

Enkapsülasyon: gıda bileşenleri, enzimler, mikroorganizmalar gibi katı veya sıvı yapılı aktif maddelerin bir kaplama materyali ile kaplanıp çevresel şartlara karşı daha dirençli hale getirilmesi olarak tanımlanır (Fang ve Bhandari, 2010). Enkapsülasyonda enkapsüle edilmiş aktif madde ve kaplama materyali olmak üzere iki farklı kısım bulunmaktadır (Cavalheiro ve ark., 2015). Kaplama materyalinin gıdaya uygun, biyobozunabilen, toksik olmayan ve aktif maddeyi koruyabilme özelliklerine sahip olması gerekmektedir. Enkapsüle edilecek aktif maddelerin kapsül içerine alınmasının temel nedeni; bu maddelerin çevresel şartlara karşı hassas olmaları sebebiyle çevresel faktörlerden etkilenmeden fonksiyonel özelliklerini korumalarını sağlamaktadır. Genel olarak, enkapsülasyon işleminde; kaplanacak malzemenin etrafında kapsülün oluşması, sızıntıların önlenmesi ve kapsül üzerindeki istenmeyen yapıların uzaklaştırılması olmak üzere üç önemli aşama bulunmaktadır (Fang ve ark., 2010). Gıda endüstrisinde kaplama materyali olarak genellikle polisakkaritler kullanılmaktadır. Ayrıca proteinler ve lipitler de enkapsülasyon için kullanılan diğer materyallerdir (Nedovic ve ark., 2011).

Hayvansal gıdalar içerdikleri protein, yağ, vitamin ve mineral madde içeriklerinden dolayı insan beslenmesinde önemli besin kaynaklarıdır (Warriss 2010). Ancak hayvansal gıdaların kimyasal ve mikrobiyolojik bozulmalara karşı duyarlı olmaları hem tüketiciler için risk oluşturmakta, hemde üreticiler için ekonomik kayıplara neden olmaktadır. Teknolojik, coğrafik ve mikrobiyolojik özelliklerinden dolayı her zaman aynı kalite ve güvenilirlikte fermente et ürünü üretmek ve tüketmek neredeyse imkansızdır. Ayrıca ısıl işlem uygulanan ürünlerde laktik asit bakterileri (LAB) içeren mikrofloranın inhibe olması yetersiz tat ve aroma oluşumu gibi bazı kalite sorunlarının ortaya çıkmasına sebep olmaktadır. Bu sebeplerle et ürünlerinde enkapsülasyon teknolojisi üzerine yapılan çalışmalar artmaktadır. Bu derleme çalışmasında et ürünlerinde ürün kalitesini artırmak, meydana gelen mikrobiyal/oksidatif bozulmaları önlemek veya en aza indir- mek için et ortamına ilave edilen enkapsüle edilmiş çeşitli gıda katkı maddeleri ve mikroorganizmalara ait yapılan çalışmalardan bahsedilmiştir.

\section{GIDA ENDÜSTRISINDE ENKAPSÜLASYON UYGU- LAMALARI}

Enkapsülasyon, materyalin kontrollü salınımını sağlayan zorlu çevresel faktörlere karşı aktif maddeyi koruma yöntemi olarak bilinir (Corbo ve ark., 2016; De Prisco ve Mauriello, 2016). Enkapsülasyon teknolojisi enkapsüle edilecek aktif maddenin; degradasyonunu azaltmak veya önlemek, dış ortama geçişini azaltmak veya önlemek, belirli bir zamanda veya ortamda dış ortama geçişini sağlamak, teknolojik açıdan kullanılabilir yapıya dönüşümünü ve gıda içerisinde homojen dağılımını sağlamak, aktif maddenin istenmeyen kokusunu veya tadını maskelemek ve gıda içerisinde bulunan bileşenlerle etkileşimini engellemek amacıyla kullanılmaktadır (Fang ve ark., 2010). Ayrıca bu teknoloji gıda endüstrisinde gıda bileşenlerinin, esansiyel yağların, aromatik hidrokarbonların, enzimlerin, mikrobiyal metabolitlerin ve mikroorganizmaların olumsuz dış şartlara karşı korunmasında kulIanım alanı bulan bir teknolojidir. Bu kapsamda asit oluşturan maddeler, aroma maddeleri, tatlandırıcılar, renklendiriciler, lipidler, vitaminler ve mineraller, enzimler ve mikroorganizmalar farklı teknikler kullanılarak enkapsüle edilebilmektedir (Desai \& Park, 2005). Gıda matrislerinde emülsiyonların kullanılması esas olarak iki temel amaca dayanmaktadır. Illk amaç, oksidasyonun önlenmesi ve kararsız bileşenlerin serbest bırakılmasını veya korunmasını kontrol etmek için aroma maddelerinin, biyoaktif bileşiklerin veya hassas yapıların enkapsüllenmesi olup, ikinci amaç ise daha sağlıklı ve az yağlı gıda ürünlerinin üretilmesidir (Öztürk ve ark., 2016).

Enkapsülasyon uygulamaları kapsül boyutuna göre nanoenkapsülasyon $(<0.2 \mu \mathrm{m})$, mikroenkapsülasyon (0.2$5,000 \mu \mathrm{m})$ ve makroenkapsülasyon $(>5,000 \mu \mathrm{m})$ olarak isimlendirilmektedir (Gökmen ve ark., 2012). Aktif maddenin etkinliğinin kapsül boyutundan olumlu veya olumsuz yönde etkilenebileceği yapılan çalışmalarda ifade edilmektedir (Hu ve ark., 2015). Enkapsülasyon materyalinin, kullanılan tekniğe, gıda tipine, maliyet ve kolay temin edilebilme gibi faktörler göz önüne alınarak seçilmesi gerekmektedir (Burgain ve ark., 2011). Enkapsülasyonda en yaygın kullanılan kaplama malzemeleri; nişasta, selüloz, alginat, pektin, karragenan ve kitosan gibi polisakkaritler, soya, peynir altı suyu, kazein, jelatin ve beta $(\beta)$-laktoglobulin gibi proteinler ve hidrojene bitkisel yağlar gibi lipidlerdir (Cavalheiro ve ark., 2015; Martín ve ark., 2015). Alginatlar ucuz, biyouyumlu ve toksik olmayan polisakkaritlerdir. Alginatların enkapsülasyon veriminin düşük olmasına rağmen yapılan çalışmalarla bu dezavantaj alginatların nişasta veya kitosan gibi polisakka- 
ritlerle kombine edilmesiyle giderilerek, kötü çevresel koşullara karşı dirençli hale getirilmiştir. (Krasaekoopt ve ark., 2003; Krasaekoopt ve ark., 2014). Alginat jelin enkapsülasyon tekniğindeki kullanımının başarısı, kaplanacak malzeme için uygun çevresel koşulların sağlaması, toksik olmayan yapısı, ucuzluğu, kolay uygulanabilirliği ve biyolojik uyumluluğundan kaynaklanmaktadır (Bilenler ve ark., 2017). Bunun yanı sıra kitosan içeriği yüksek mikrokapsüller ise, daha fazla aktif maddenin enkapsüle edilmesini ve yavaşça serbest bırakılmasını sağlama özelliğindedir (Hu ve ark., 2015).

\section{LAB VE PROBIYOTIKLERIN ENKAPSÜLASYONU}

Probiyotik, yaşam için anlamına gelen ve genellikle insanlar ve hayvanlar için yararlı etkiler gösteren bakterileri tanımlamakta kullanılır. Uzmanlar tarafından probiyotikler "yeterli miktarda tüketilmeleri sonucu konakçı üzerinde olumlu sağlık etkileri yaratan canlı mikroorganizmalar" olarak tanımlanmaktadır (FAO/WHO 2001). LAB raf ömrünü uzatıcı, duyusal özellikleri geliştirici ve besin değerini artırıcı etkilerinden dolayı fermente et ürünlerinde yaygın olarak kullanılmaktadır (Hammes 2012). Gıdaların işlenmesi, depolanması ve tüketilmesi boyunca kullanılan probiyotik mikroorganizmaların canlılığını sağlayan ve koruyan metotlardan en etkilisinin enkapsülasyon teknolojisi olduğu bildirilmiştir (De Prisco ve Mauriello, 2016). Fermente et ürünlerinde fermantasyon sırasında başlatıcı kültürlerin veya probiyotiklerin gelişiminde tuz konsantrasyonu, nitrat/nitrit içeriği, et/yağ yüzey gerilimi ve baharat içeriği gibi faktörler etkili olabilmektedir. Bakterilerin fermantasyon şartlarına rahatça adapte olabilmeleri, fermantasyonun etkinliği, spesifik ürün karakteristiğinin oluşabilmesi ve fermantasyon sonunda başlatıcı kültür sayısında meydana gelen kaybı azaltmak için enkapsülasyon teknolojisinden faydalanılmaktadır (Bilenler ve ark., 2017).

Et endüstrisinde mikrobiyal kontaminasyon, lipit ve protein oksidasyonu problemleri ile sıklıkla karşılaşılmaktadır. Bu nedenle et ve et ürünlerinde gıda güvenliği ve kalite parametrelerinin korunması amacıyla, katkı maddeleri yaygın bir kullanım alanına sahiptir. Enkapsüle edilmiş katkı maddeleri veya probiyotik mikroorganizmalar çevresel şartlara daha dirençli hale gelerek uzun süre ortamda etkinliklerini koruyabilmektedir. Bu sebeplerle son yıllarda enkapsülasyon teknolojisi ile gıdaların aromasını, stabilitesini ve raf ömrünü kontrol etmek ve pro- biyotikleri gıda içerisinde daha etkili koruyabilmek amacıyla yapılan çalışmalar artmıştır (Burgain ve ark., 2011). Bu kapsamda alginatla enkapsüle edilen probiyotik suşları, dondurma, peynir, yoğurt ve mayonez gibi gıdaların formülasyonlarında kullanılmıştır (Corona-Hernandez ve ark., 2013). Probiyotik mikroorganizma kullanılarak üretilen ürünlerde probiyotiklerin proses sırasında canlılıklarını yitirmeleri ve son üründe canlı mikroorganizmaların sayısının düşük olması probiyotik mikroorganizmaların enkapsüle edilmesine neden olmuş ve neticede enkapsülasyon uygulamaları popüler hale gelmiştir (Kailasapathy 2009). Enkapsülasyon işleminin başarı göstergelerinden birisi son üründeki canlı probiyotik mikroorganizmaların sayısıdır. Proses uygulamaları, kaplama materyali ve enkapsülasyon teknikleri probiyotik mikroorganizmalarının sayısı üzerine oldukça etkilidir (Idris ve ark., 2006; Zain ve ark., 2011). Enkapsülasyon işlemi öncesi ve sonrasında canlı probiyotik mikroorganizmaların sayısı "enkapsülasyon verimi" olarak ifade edilir (Heidebach ve ark., 2012). Probiyotiklerin enkapsülasyonunda genellikle ekstrüzyon, emülsifikasyon, püskürterek ve dondurarak kurutma gibi enkapsülasyon teknikleri kullanılmaktadır (Rathore ve ark., 2013). Püskürterek kurutma tekniğiyle yapılan enkapsülasyon işleminin LAB'nin ısıl işlem sırasında ve sonrasında canlılıklarının muhafaza edilmesi için etkili yollardan birisi olduğu kanıtlanmıştır (Pérez-Chabela ve ark., 2013).

Enkapsülasyon teknolojisi ile, farklı matrisler kullanarak probiyotik mikroorganizmaların et ürünlerinin işlenmesi, depolanması ve pişirilmesi aşamalarında olumsuz ortam koşullarından korunması ve gastrointestinal bölgeye canlılıklarını koruyarak ulaşması sağlanabilmektedir. Enkapsüle edilen mikroorganizmaların canlı kalma oranının \% 80-95'e kadar arttırdığı bildirilmektedir (Martín ve ark., 2015). Probiyotik mikroorganizmaların enkapsülasyonu sırasında dikkat edilecek önemli hususlardan birisi; kaplama materyalinin depolama süresi boyunca hücrelerin canlılığını devam ettirebilecek nitelikte olmasıdır. Alginat, buğday proteinleri ve Arap zamkının; sucuk (Sidira ve ark., 2014a), salam (Barbosa ve ark., 2015) ve pişmiş et ürünleri (Perez- Chabela ve ark., 2013) üretiminde probiyotik bakterilerin enkapsüle edilmesi için kaplama malzemeleri olarak kullanılabileceği belirtilmektedir. Et ürünlerinde kullanılan enkapsüle probiyotik mikroorganizmalar Tablo 1'de verilmiştir. 
Tablo 1. Et ürünlerinde kullanılan enkapsüle edilmiş probiyotik mikroorganizmalar

\begin{tabular}{llll}
\hline Ürün & Mikroorganizma & Kaplama materyali & Referans \\
\hline Fermente sosis & $\begin{array}{l}\text { L. plantarum, } \\
\text { P. pentosaceus }\end{array}$ & Kalsiyum alginat & Kearney ve ark. (1990) \\
\hline Fermente sosis & L. reuteri & Sodyum alginat & $\begin{array}{l}\text { Muthukumarasamy ve } \\
\text { Holley (2006) }\end{array}$ \\
\hline Fermente sosis & $\begin{array}{l}\text { L. reuteri, } \\
\text { B. longum }\end{array}$ & Sodyum alginat & $\begin{array}{l}\text { Muthukumarasamy ve } \\
\text { Holley (2007) }\end{array}$ \\
\hline Pişirilmiş et ürünleri & $\begin{array}{l}\text { A. viridans, } \\
\text { E. faecium, }\end{array}$ & Arap zamkı & $\begin{array}{l}\text { Perez-Chabela ve ark. } \\
\text { (2013) }\end{array}$ \\
& $\begin{array}{l}\text { L. plantarum, } \\
\text { P. pentosaceus }\end{array}$ & & \\
\hline Fermente sosis & L. casei & Buğday proteini & $\begin{array}{l}\text { Sidira ve ark. (2014a) } \\
\text { Sidira ve ark. (2014b) }\end{array}$ \\
\hline Salam & L. curvatus & Sodyum alginat & Barbosa ve ark. (2015) \\
\hline Fermente sosis & L. casei & Buğday proteini & Sidira ve ark. (2015) \\
\hline Et model sistemi & 4 tane L.plantarum suşu & Sodyum alginat & Corbo ve ark. (2016) \\
\hline Sucuk & L. rhamnosus & Alginat, jelatin, gellan & Turhan ve ark. (2017) \\
& & $\begin{array}{l}\text { zamk ve fruktooligosak- } \\
\text { karit }\end{array}$ & \\
\hline Fermente sosis & B. longum & Gliserol & Song ve ark. (2018) \\
\hline Jambon & B. animalis & Peynir altı suyu proteini & Pereira ve ark. (2018) \\
\hline
\end{tabular}

Yapılan bir çalışmada probiyotik mikroorganizmaların enkapsüle edilerek $55-65^{\circ} \mathrm{C}$ 'de gerçekleşen Isıl işlem uygulamalarında canlılıklarını muhafaza ettikleri belirlenmiştir (Mandal ve ark., 2006). Ayrıca fermente et ürünlerinde yapılan bir çalışmada sodyum alginat kullanılarak enkapsüle edilen Lactobacillus reuteri ATCC 55730 suşu kullanılmış ve fermantasyon süresinde enkapsüle edilmemiş gruplarda bakteri sayısı 2.6 log $\mathrm{KOB} / \mathrm{g}$ 'a kadar düşerken, alginat ile enkapsüle edilen probiyotik mikroorganizmaların bulunduğu grupta önemli bir değişikliğin olmadığı ifade edilmiştir. Araştırmacılar ayrıca, enkapsüle ve enkapsüle edilmemiş formdaki probiyotik kültürlerin kombinasyonuyla Esherichia coli O157:H7'nin etkili bir şekilde inaktive olabildiğini ifade etmişlerdir (Muthukumarasamy ve ark., 2007).

Fermente et model sisteminde LAB'nin enkapsüle edilmesinde alginatların uygun bir kaplama materyali olduğu ve alginatla enkapsüle edilen LAB içeren deney gruplarının fermantasyon süresi sonunda ürünün asitliğinin enkapsüle edilmemiş LAB içeren kontrol grubuna benzer olduğu ifade edilmiştir (Corbo ve ark., 2016). Benzer bir çalışmada probiyotik sucuk üretiminde $L$. caseinin buğday proteinleri ile enkapsüle edildiğinde, bakterinin fermantasyon şartlarında canlıı̆̆ını koruduğu ve probiyotik sucuk üretimi için uygun bir başlatıcı kültür olduğu ifade edilmiştir (Sidira ve ark., 2014b). Yapılan çalışmalarda, bakteriyosin üreticisi LAB'nin kalsiyum alginatla enkapsüle edilmesiyle bakteriyosinin koruyucu etkisinin azaldığı görülmektedir. Bakteriyosin üreticisi LAB'nin enkap- süle edilmesi sırasında biyokoruyucu etkinin azalmaması için yarı saflaştırılmış bakteriyosin/bakteri karışımlarının birden fazla fosfolipit tabaka (lipozom) ile enkapsüle edilmesinin alginat tekniğine kıyasla daha etkili olduğu ifade edilmiştir (Mills ve ark., 2011; Zou ve ark., 2012).

Cavalheiro ve ark. (2015) tarafından yapılan araştırmada, inulin, trehaloz ve süt tozu ile enkapsüle edilen $L$. plantarum'un ısıl işleme karşı direnç kazanarak, kademeli olarak arttırılan sıcaklıklara karşı canlıığını koruyabildiği belirtmiştir. Yapılan başka bir araştırmada ise, enkapsüle edilmiş probiyotik içeren ısıl işlem görmüş et ürünlerinin, enkapsüle edilmemiş probiyotik içeren gruba kıyasla daha yüksek miktarda LAB içerdiği, LAB sayısının depolama süresi boyunca artıı̆ı ve 8 günlük depolamanın sonunda 6 log KOB/g'dan daha yüksek değerlere ulaştığı ifade edilmiştir. Isıl işlem görmüş et ürünlerinde probiyotik mikroorganizma içeren kapsüllerin Enterobacteriaceae üyelerine karşı biyokoruyucu etki gösterdiği kanıtlanmıştır (Pérez-Chabela ve ark., 2013).

Barbosa ve ark. (2015) salamdan izole edilen bakteriyosin üreticisi $L$. curvatus MBSa2 suşunun enkapsüle edilmiş ve edilmemiş iki formda ürüne ilave edildiğinde Listeria monocytogenesin inhibisyonu üzerinde etkisinin önemli olmadığını, ancak enkapsüle edilmiş $L$. curvatus MBSa2'nin sayısının, depolama boyunca enkapsüle edilmemiş L. curvatus MBSa2'ye göre yüksek olduğunu ifade etmişlerdir. Wang ve ark. (2015) ise sodyum algi- 
nat, jellan ve yağsız süt tozu ile enkapsüle edilen $L$. kefiranofaciens M1 suşunun sıcaklık toleransının 25 ${ }^{\circ} \mathrm{C}$ 'den $75^{\circ} \mathrm{C}$ 'ye yükseldiğini ve enkapsüle edilmemiş $L$. kefiranofaciens M1 suşu tamamen inhibe olurken, enkapsüle edilmiş $L$. kefiranofaciens M1 suşunun sayısında $1 \log \mathrm{KOB} / \mathrm{g}$ azalma meydana geldiği belirtilmiştir. Isıl işlem görmüş fermente et ürünlerinde enkapsüle edilmiş Staphylococcus xylosus ve L. plantarum'un sayısının sadece 1 log KOB/g azaldığı ve enkapsüle edilmiş mikroorganizmaları içeren grupta, enkapsüle edilmemiş mikroorganizma içeren gruba kıyasla asitliğin yeterince oluştuğu ve kalıntı nitrat miktarının düşük olduğu da ifade edilmiştir (Bilenler ve ark., 2017).

\section{PATOJENLERIN INNHIBISYONUNDA ENKAPSÜLAS- YON TEKNOLOJISI KULLANIMI}

Esansiyel yağların uçucu olması ve çevresel şartlardan kolay etkilenebilmesi gibi nedenlerden dolayı enkapsüle edilerek kullanılması tavsiye edilmektedir. Et ürünlerinde lipit oksidasyonun azaltılması (Du ve Claus 2015; Claus ve ark., 2016), yağ asidi profilinin geliştirilmesi (Ojha ve ark., 2017), antioksidan içeren ambalaj malzemelerinin üretilmesi (Wrona ve ark., 2017), et ürünlerinin fizikokimyasal özelliklerinin (Özvural ve ark., 2016) arttırılması için enkapsülasyon teknolojisinden yararlanılmaktadır. Enkapsüle edilmiş esansiyel yağların enkapsüle edilmemiş esansiyel yağlarla kıyaslandığında antimikrobiyal aktivitelerinin daha stabil, oksidasyona karşı dayanıklılığın üründe arttığı ve ürünün uçucu bileşenlerinde daha az kayıplar oluştuğu belirtilmiştir (Arana-S'anchez ve ark., 2010).

Saloko ve ark. (2014) kitosan ve maltodesktrini farklı oranlarda (F1: Kitosan $(0.5 \% \mathrm{w} / \mathrm{v})$ ve MD $(9.5 \% \mathrm{w} / \mathrm{v})$, F2: Kitosan: MD (0\%: 10\%) ve F2: Kitosan: MD (1.5\%: 8.5\%) kullanarak hazırladığı kaplama materyalleri ile sıvı tütsü aromasını enkapsüle ederek patojenlere karşı etkisini araştırmışlardır. Çalışma sonucunda, F1 formulasyonunun Staphylococcus aureus, Bacillus subtilis, Escherichia coli ve Pseudomonas fluoroscens'e karşı antimikrobiyal aktivite göstermediği, F2 ve F3 formulasyonunun Gram pozitiflere kıyasla Gram negatiflerde daha fazla antimikrobiyal etki göstediği ortaya konmuştur. Hu ve ark. (2015) tarafından yapılan çalışmada ise, kitosan ile enkapsüle edilmiş tarçın yağının enkapsüle edilmemiş tarçın yağına kıyasla dondurulmuş domuz etinde daha etkili antioksidan ve antimikrobiyal etki gösterdiği ve 112 $\mathrm{nm}, 215 \mathrm{~nm}$ ve $527 \mathrm{~nm}$ kapsül boyutları kıyaslandığında en yüksek antimikrobiyal ve antioksidan etkinin $527 \mathrm{~nm}$ boyuta sahip enkapsüle tarçın yağında gözlemlendiği belirtilmiştir. Başka bir araştırmada ise, L. monocytogenes'in inhibisyonunda rol oynayan nisin, tarçın ve keklik otu (oregano) esansiyel yağlarının etkinliğini artırmak için alginat ile enkapsüle edilmiş keklik otu yağı ve nisin içeren gruplarda 35 günlük depolama sonucunda et ürünlerinde $L$. monocytogenes sayısının ışınlama uygulamalarıyla 1.07 log KOB/g'a kadar düştüğü tespit edilmiştir (Huq ve ark., 2015).

Haidan ve ark. (2017) tarafından yapılan bir çalışmada kitosan-benzoik asitle enkapsüle edilmiş biberiye esansiyel yağının enkapsüle edilmemiş biberiye esansiyel yağına kıyasla dana pirzolada bulunan Salmonella sayısının azalmasında daha etkili olduğu ve $2 \mathrm{mg} / \mathrm{g}$ düzeyinde enkapsüle biberiye yağının patojenlerin sayısında 6 log gibi önemli bir azalma meydana getirdiği ifade edilmiştir. Araştırmacılar patojenlerin sayısının azaltılması ve raf ömrünün uzaltılmasında biberiye esansiyel yağının enkapsüle edilerek kullanılmasını önermektedir. Tavuk etinde yapılan benzer bir çalışmada lipozom içerisine enkapsüle edilmiş kekik yağının enkapsüle edilmemiş kekik yağına kıyasla Salmonella'ya karşı daha uzun süre inhibisyon etki gösterdiği tespit edilmiştir (Cui ve ark., 2017). Yapılan başka bir çalışmada ise; enkapsüle karanfil yağının enkapsüle edilmemiş karanfil yağına kıyasla daha düşük antioksidan aktivite göstermesine rağmen patojenlerin inhibisyonunda daha etkili olduğu ifade edilmiştir (Radünz ve ark., 2019). Ayrıca araştırmacılar enkapsüle karanfil yağının $S$. aureus ve Salmonella Typhimurium'a karşı bakterisidial etki gösterdiği ve bu yüzden işlenmiş et ürünlerinde nitrite benzer koruyucu bir etki gösterdiğini rapor etmişlerdir .

Bakteriyofajların termal stabilitesini artırarak et ürünlerinde patojen/bozucu mikroorganizmaların inhibisyonunu sağlamak amacıyla da enkapsülasyon teknolojisinden yararlanımaktadır. Tüketime hazır et ürünlerinde Listeria tehlikesini ortadan kaldırmaya yönelik yapılan bir çalışmada, sıcaklığa duyarlı Listeria fajlarının sodyum alginat ile kaplanarak termostabilitesi arttırılmış, A511 fajının et yüzeyinde $L$. monocytogenes'i etkili şekilde inaktive ettiği ifade edilmiştir (Ahmadi 2017). Alves ve ark. (2019) yapılan çalışmada ise, sodyum alginat ile enkapsüle edilmiş фIBB-PF7A fajı ile muamele edilen Pseudomonas fluorescens bulaştırılmış tavuk eti filetolarında $P$. fluorescens sayısının ilk iki günde 2 log azaldığı ve bu etkinin depolamanın 5. gününe kadar 3 log olarak devam ettiği ifade edilmiştir.

\section{ET ÜRÜNÜNLERININ KALITESININ ARTTIRILMA- SINDA ENKAPSÜLASYON TEKNOLOJISININ KUL- LANIMI}

Fermente et ürünlerinin üretiminde kullanılan hayvansal yağların diğer yağ kaynaklarıyla modifiye edilmesi ürünün besleyici değerinin artmasına ve istenilen ürün karakteristiğinin oluşmasını sağlamaktadır (Triki ve ark., 2013). Benzer şekilde fermente et ürünlerine katılan hayvansal yağ yerine enkapsüle edilmiş doymamış yağ asitlerinin kullanılmasının teknolojik bakımdan sorun 
oluşturmadığı ve sağlıklı gıdaların üretimine katkıda bulunduğu ifade edilmiştir (Pavlík ve ark., 2014). Gıdaların işlenmesi ve depolanması sırasında uçucu yağların bozulması ve kaybını azaltmak için kullanılmadan önce enkapsüle edilmesi olumlu etkiler göstermektedir (Hill ve ark., 2013). Balık yağlarına antioksidan ilavesi veya balık yağlarının enkapsüle edilmesi ile oksidasyon hassasiyeti düşürülmekte ve çoklu doymamış yağ asitleri gibi hassas yapılara nem ve oksijen geçişi sınırlandırılarak, oksidasyon kararlıı̆̆ı arttırılmaktadır (Baik ve ark., 2004). Balık yağlarının enkapsülasyonu, çoklu doymamış yağ asitlerinin okside olmasını önlemekte, böylelikle besin değerinin kaybını ve tadın bozulmasını engellemektedir. Bu amaçla yapılan bir çalışmada, pullulan ve laktozla enkapsüle edilmiş balık yağı içeren iki farklı deney grubunun, depolama sonucunda enkapsüle edilmemiş balık yağı içeren kontrol grubuna kıyasla daha az okside olduğu ve pullulan ile enkapsüle edilmiş deney grubunun laktoz ile enkapsüle edilmiş deney grubuna kıyasla daha iyi koruma sağladığı belirtilmiştir (Koç ve ark., 2008). Kılıç ve ark. (2016a) tarafından yapılan çalışmada, enkapsüle edilmiş sodyum tripolifosfat ve sodyum pirofosfat'ın kontrol gruplara kıyasla daha yüksek antioksidan aktivite gösterdiği ve bu aktivitenin kapsüllerin yüksek erime sıcaklığıyla arttırıldığı belirtilmiştir. Kılıç ve ark. (2018a) tarafından yapılan başka bir çalışmada ise; tüketime hazır et ürünlerinin oksidasyon stabilitesini arttırmak için et ürünlerine pişirme öncesi \% 0.25 enkapsüle edilmiş fosfat ilave edilmesinin önemi ortaya konmuştur. Yapılan benzer çalışmalarda; et ürünlerine ilave edilen polifosfatların enkapsüle edilmiş fosfatlarla kombine edilerek kullanılmasının, et ürünlerinin kalite sorunlarından biri olan lipit oksidasyonu engellediği tespit edilmiş ve üreticilere enkapsüle edilmiş fosfat içeren formülasyonların kullanımı önerilmiştir (Kılıç ve ark., 2016b; Kılıç ve ark., 2018b).

Etlerin gevrekleştirilmesinde yaygın olarak kullanılan enzimlerden biri olan bromelain enziminin lipozom içerisine enkapsüle edilmesiyle bromelain aktivitesinin korunduğu ve artan sıcaklık değerleriyle kontrollü olarak salınması sonucunda istenilen et karakteristiğinin oluşmasına yardımcı olduğu ifade edilmektedir (Lee ve ark., 2000). Comunian ve ark. (2014) ise, tavuk sosislerinde antioksidan olarak kullanılan sodyum eritorbat yerine enkapsüle askorbik asit kullanımının ürünün duyusal özelliklerini değiştirmediği, besin değerini arttırdığı, su aktivitesi ve nem içeriğini koruduğunu ifade etmiş ve enkapsüle askorbik asit kullanımının ticari antioksidanların yerini alabileceğini belirtilmişlerdir. Ayrıca kapsülün zamanla bozunması sırasında askorbik asidin kontrollü olarak salınımı sonucunda oksidasyon hızının yavaşladığı ifade edilmiştir

\section{SONUÇ}

Enkapsülasyon teknolojisi, üstün özellikleri bakımından sağlık, farmakoloji ve ziraat gibi bir çok alanda yaygın olarak kullanılan bir teknolojidir. Teknolojik avantajları gıda biliminin de ilgisini çekmiştir. Et ürünlerinin üretiminde işlenecek et kalitesini etkileyen coğrafik ve iklimsel sebepler, hayvanın sağlık durumu, hayvanın yaşı, yem kalitesi, etin karakteristik yapısı, işleme ve depolama koşulları, üretim alanının hijyeni ve sanitasyonu gibi parametreler son ürünün kalitesinin belirlenmesinde önemli rol oynamaktadır. Fermantasyon ve pişirme gibi proses uygulamaları sırasında gıda bileşenlerinde kayıplar meydana gelmektedir.

Yapılan araştırmalar, ürüne işlenecek etin kalitesini arttırmada enkapsülasyon tekniğinin kullanılmasının; kalite parametrelerinin olumsuz etkisini azaltarak, homojen ve daha az kalite kaybına uğramış ham maddenin elde edilmesini sağlayarak üretim maliyetinin düşürebileceğini kanıtlamıştır. Et ürünlerinin üretiminde kullanılan antimikrobiyal, antioksidan ve emülsifiye edici ajanların enkapsüle edilmiş formları, enkapsüle edilmemiş formlarına kıyasla depolama süresi boyunca daha uzun süre aktiviteleri göstermektedir.

Fermantasyon ortamına enkapsüle edilmiş başlatıcı kültürlerin ilave edilmesiyle, nitrit/nitratın başlatıcı kültür üzerine olan olumsuz etkisi azaltılmakta, baharat ve et/yağ yüzey geriliminden daha az etkilenmektedir. Yapılan çalışmalarda enkapsüle edilmiş bakteriyosin üreticisi kültürlerden beklenilen antimikrobiyal etki tam olarak gözlemlenememiştir. Beklenilen etkinin gözlemlenebilmesi için enkapsüle edilmiş ve edilmemiş bakteriyosin üreticisi başlatıcı kültürlerin birlikte kullanıldığı çalışmaların sayısının artması gerekmektedir. Probiyotik mikroorganizmaların et matrisinde canlılığını devam ettirebilmesi enkapsülasyon teknolosiyle mümkün olmaktadır.

Et ürünlerinde patojenlerin inhibisyonunda bakteriyofaj kullanımı ısıl işlem uygulamalarından dolayı sınırlandırılmaktadır. Bakteriyofajların enkapsüle edilmesiyle bu sınırlandırma ortadan kalkmaktadır. Patojenlere karşı kullanılan diğer bir mücadele yöntemi olan doğal kaynakların kullanımına bakıldığında et ürünlerine ilave edilen bitkisel özüt/esansiyel yağları içeren kapsül zamanla bozularak, ürünün depolamalanması sürecinde bakterisidal ve/veya bakteriyostatik etki göstermektedir. Sonuç olarak, et ürünlerinin kalitesinin arttırımasında kullanılan enzimler, katkı maddeleri, esansiyel yağlar, ekstraktlar ve mikroorganizmaların etkinliğini sağlamak için enkapsülasyon teknolojisine intiyaç duyulmaktadır. Gıda bileşenlerine uygun kaplama materyalinin belirlenmesi amacıyla yapılan bilimsel çalışmaların artmasının ve elde 
edilen sonuçların sektörde uygulama imkanlarının yaygınlaştırımasının et endüstrisinde önemli katkı sağlayacağı düşünülmektedir.

\section{KAYNAKLAR}

Ahmadi, H. (2017). Thermal stability of encapsulated Listeria bacteriophage and its efficacy against Listeria monocytogenes in ready-to-eat meats (PhD thesis). University of Guelph.

Alves, D., Marques, A., Milho, C., Costa, M. J., Pastrana, L. M. Cerqueira, M. A., Sillankorva, S. M. (2019). Bacteriophage $\phi I B B-P F 7 A$ loaded on sodium alginate-based films to prevent microbial meat spoilage. International journal of food microbiology, 291: 121-127.

Arana-S'anchez, A., Estarr'on-Espinosa, M., E. N. ObledoV'azquez, E. Padilla-Camberos, R. Silva-V'azquez, E. Lugo- Cervantes. (2010). Antimicrobial and antioxidant activities of Mexican oregano essential oils (Lippia graveolens $\mathrm{H}$. B. K.) with different composition when microencapsulated in $\beta$-cyclodextrin, Letters in Applied Microbiology, 50: 585-590.

Baik, M. Y., Suhendro, E. L., Nawar, W. W., McClements, D. J., Decker, E. A., Chinachoti, P. (2004). Effects of antioxidants and humidity on the oxidative stability of microencapsulated fish oil. Journal of the American Oil Chemists' Society, 81 : 355-360.

Barbosa, M. S., Todorov, S. D., Jurkiewicz, C. H., Franco, B. D. (2015). Bacteriocin production by Lactobacillus curvatus MBSa2 entrapped in calcium alginate during ripening of salami for control of Listeria monocytogenes. Food Control, 47: 147-153.

Bilenler, T., Karabulut, I., Candogan, K. (2017). Effects of encapsulated starter cultures on microbial and physicochemical properties of traditionally produced and heat treated sausages (sucuks). LWT-Food Science and Technology, 75: 425-433.

Burgain, J., Gaiani, C., Linder, M., Scher, J. (2011). Encapsulation of probiotic living cells: from laboratory scale to industrial applications. Journal of Food Engineering, 104: 467-483.

Cavalheiro, C. P., Menezes, C. R., Fries, L. L. M., Ruiz-Capillas, C., Herrero, A. M., Jimeenez-Colmenero, F. (2015). Alginate beads to improve viability of Lactobacillus plantarum to heat stress. Journal of Food Processing and Technology, 6: 126.

Champagne, C. P., Lee, B. H., Saucier, L. (2010). Immobilization of cells and enzymes for fermented dairy or meat products. In N. J. Zuidam, \& V. A. Nedović (Eds.), Encapsulation technologies for active food ingredients and food processing (pp. 345-365). London: Springer.

Claus, J., Du, C., Kılıç, B. (2016). Inhibition of lipid oxidation in ground turkey breasts by encapsulated Polyphosphates as influenced by postmortem pH. Meat Science, (112), 129.

Comunian, A., Thomazini, M., Gambagorte, V. F., Trindade, M. A., Favaro-Trindade, C. S. (2014). Effect of incorporating free or encapsulated ascorbic acid in chicken frankfurters on physicochemical and sensory stability. J. Food Sci. Eng, 167-175.

Corbo, M. R., Bevilacqua, A., Speranza, B., Maggio, B. D., Gallo, M., Sinigaglia, M. (2016). Use of alginate beads as carriers for lactic acid bacteria in a structured system and preliminary validation in a meat product. Meat Science, 111: 198-203.

Corona-Hernandez, R. I., Alvarez-Parilla, E., Lizardi-Mendoza, J., Islas-Rubio, A. R., de la Rosa, A., \& Wall-Medrano, A. (2013). Structural stability and viability of microencapsulated probiotic bacteria: A review. Comprehensive Reviews in Food Science and Food Safety, 12: 614-628.

Cui, H., Yuan, L., Ma, C., Li, C., Lin, L. (2017). Effect of nianoliposome-encapsulated thyme oil on growth of Salmonella Enteritidis in chicken. Journal of Food Processing and Preservation, 41: 13299.

De Prisco, A., Mauriello, G. (2016). Probiotication of foods: A focus on microencapsulation tool. Trends in Food Science \& Technology. 48: 27-39.

Desai, K. G. H., Park, H. J. (2005). Recent developments in microencapsulation of food ingredients. Drying Technology, 23: 1361-1394.

dos Reis, A. S., Diedrich, C., de Moura, C., Pereira, D., de Flório Almeida, J., da Silva, L. D., Carpes, S. T. (2017). Physico-chemical characteristics of microencapsulated propolis co-product extract and its effect on storage stability of burger meat during storage at- $15^{\circ} \mathrm{C}$. LWT-Food Science and Technology, 76: 306-313.

Du, C., Claus, J. R. (2015). Inhibition of lipid oxidation in ground turkey with encapsulated phosphates as affected by meat age, phosphate type, and temperature release point. Meat Science, (101), 110.

Fang, Z., Bhandari, B. (2010). Encapsulation of polyphenols a review. Trends in Food Science \& Technology, 21: 510523.

Gökmen, S., Palamutoğlu, R., Sarıçoban, C. (2012). Applications of Encapsulation in Food Industry. Electronic Journal of Food Technologies 7: 36-50.

Hadian, M., Rajaei, A., Mohsenifar, A., Tabatabaei, M. (2017). Encapsulation of Rosmarinus officinalis essential oils in chitosan-benzoic acid nanogel with enhanced antibacterial activity in beef cutlet against Salmonella Ttyphimurium during refrigerated storage. LWT-Food Science and Technology, 84: 394-401.

Hammes, W. P. (2012). Metabolism of nitrate in fermented meats: the characteristic feature of a specific group of fermented foods. Food Microbiology, 29: 151-156.

Heidebach, T., F€orst, P., Kulozik, U. (2012). Microencapsulation of probiotic cells for food applications. Critical Reviews in Food Science and Nutrition, 52: 291-311.

Hill, E. L., Gomes, C., Taylor, M. T. (2013). Characterization of beta-cyclodextrin inclusion complexes containing essential oils (trans-cinnamaldehyde, eugenol, cinnamon bark, and clove bud extracts) for antimicrobial delivery applications. LWT-Food Science and Technology, 51: 86-93.

Hu, J., Wang, X., Xiao, Z., Bi, W. (2015). Effect of chitosan nanoparticles loaded with cinnamon essential oil on the quality of chilled pork. LWT-Food Science and Technology, 63: 519-526

Huq, T., Vu, K. D., Riedl, B., Bouchard, J., Lacroix, M. (2015). Synergistic effect of gamma ( $\mathrm{Y}$ )-irradiation and microencapsulated antimicrobials against Listeria monocytogenes on ready-to-eat (RTE) meat. Food Microbiology, 46: 507514.

Idris, A., Suzana, W. (2006). Effect of sodium alginate concentration, bead diameter, initial $\mathrm{pH}$ and temperature on lactic acid production from pineapple waste using immobilized 
Lactobacillus delbrueckii. Process Biochemistry, 41: 11171123.

Kearney, L., Upton, M., McLoughlin, A. (1990). Meat fermentations with immobilized lactic acid bacteria. Applied Microbiology and Biotechnology, 33: 648e651.

Kılıç, B., Şimşek, A., Claus, J. R., Atılgan, E. (2016a). Melting release point of encapsulated phosphates and heating rate effects on control of lipid oxidation in cooked ground meat. LWT-Food Science and Technology, 66: 398-405.

Kılıç, B., Şimşek, A., Claus, J. R., Atılgan, E., Bilecen, D. (2016b). Impact of Added Encapsulated Phosphate Level on Lipid Oxidation Inhibition during the Storage of Cooked Ground Meat. Journal of food science, 81(2), C359-C368.

Kılıç, B., Şimşek, A., Claus, J. R., Karaca, E., Bilecen, D. (2018a). Improving lipid oxidation inhibition in cooked beef hamburger patties during refrigerated storage with encapsulated polyphosphate incorporation. LWT-Food Science and Technology, 92: 290-296.

Kılıç, B., Şimşek, A., Claus, J. R., Karaca, E., Bilecen, D. (2018b). Inhibition of Lipid Oxidation by Using a Combination of Encapsulated and Unencapsulated Polyphosphates in Cooked Ground Meat during Storage. Meat and Muscle Biology, 1:21-21.

Koç, M., Met, A., Sakin, M., Kaymak-Ertekin, F. (2008). Balık yağının dondurarak kurutma yöntemiyle mikroenkapsüle edilmesi. 10. Gıda Kongresi; 21-23 Mayıs 2008, Erzurum, Türkiye, 10, 21-23.

Krasaekoopt, W., Watcharapoka, S. (2014). Effect of inulin and galactooligosaccharide on the survival of microencapsulated probiotics in alginate beads coated with chitosan in simulated digestive system, yogurt and fruit juice. LWT-Food Science and Technology, 57: 761-766.

Krasaekoopt, W., Bhandari, B., Deeth, H. (2003). Evaluation of encapsulation techniques of probiotics for yoghurt. International Dairy Journal, 13: 3-13.

Krasaekoopt, W., Bhandari, B., Deeth, H. (2004). The influence of coating material on some properties of alginate beads and survivability of microencapsulated probiotic bacteria. International Dairy Journal, 14: 737-743.

Lee, D. H., Jin, B. H., Hwang, Y. I., Lee, S. C. (2000). Encapsulation of bromelain in liposome. Journal of food science and nutrition, 5: 81-85.

Mandal, S., Puniya, A. K., Singh, K. (2006). Effect of alginate concentration on survival of microencapsulated LactobacilIus casei NCDC-298. International Dairy Journal, 16: 11901195.

Martín, M. J., Lara-Villoslada, F., Ruiz, M. A., Morales, M. E. (2015). Microencapsulation of bacteria: A review of different technologies and their impact on the probiotic effects. Innovative Food Science and Emerging Technologies, 27: 15-25.

McClements D., Lesmes U, (2009). Structure-function relationships to guide rational design and fabrication of particulate food delivery systems. Trends Food Sci Technol; 20: 448-57.

Mills, S., Stanton, C., Hill, C., Ross, R. P. (2011). New developments and applications of bacteriocins and peptides in foods. Annual Reviews in Food Science and Technology, 2: 299-329

Muthukumarasamy, P., Holley, R. A. (2006). Microbiological and sensory quality of dry fermented sausages containing alginate-microencapsulated Lactobacillus reuteri. International Journal of Food Microbiology, 111: 164-169.
Muthukumarasamy, P., Holley, R. A. (2007). Survival of Escherichia coli $\mathrm{O} 157: \mathrm{H} 7$ in dry fermented sausages containing micro-encapsulated probiotic lactic acid bacteria. Food Microbiology, 24: 82-88.

Nedovic, V., Kalusevic, A., Manojlovic, V., Levic, S., Bugarski, B. (2011). An overview of encapsulation technologies for food applications. Procedia Food Science, 1: 1806-1815.

Ojha, K. S., Perussello, C. A., García, C. Á., Kerry, J. P., Pando, D., Tiwari, B. K. (2017). Ultrasonic-assisted incorporation of Nano-encapsulated omega-3 fatty acids to enhance the fatty acid profile of pork meat. Meat science, 132: 99-106.

Öztürk, B., Urgu, M., Serdaroğlu, M. (2016). Egg white powderstabilised multiple (water-in-olive oil-in-water) emulsions as beef fat replacers in model system meat emulsions. Journal of the Science of Food and Agriculture (Basılmamış).

Özvural, E. B., Huang, Q., Chikindas, M. L. (2016). The comparison of quality and microbiological characteristic of hamburger patties enriched with green tea extract using three techniques: Direct addition, edible coating and encapsulation. LWT-Food Science and Technology, 68: 385-390.

Pavlík, Z., Saláková, A., Kameník, J., Pospíšil, J., Králová, M., Steinhauserová, I. (2014). Effect of micro-encapsulated n3 fatty acids on quality properties of two types of dry sausages. Acta Veterinaria Brno, 83: 163-169.

Pereira, J. O., Soares, J., Monteiro, M. J., Gomes, A., Pintado, M. (2018). Impact of whey protein coating incorporated with Bifidobacterium and Lactobacillus on sliced ham properties. Meat science, 139: 125-133.

Pérez-Chabela, M. L., Lara-Labastida, R., Rodriguez-Huezo, E., Totosaus, A. (2013). Effect of spray drying encapsulation of thermotolerant lactic acid bacteria on meat batters properties. Food and Bioprocess Technology, 6: 15051515.

Radünz, M., da Trindade, M. L. M., Camargo, T. M., Radünz, A. L., Borges, C. D., Gandra, E. A., Helbig, E. (2019). Antimicrobial and antioxidant activity of unencapsulated and encapsulated clove (Syzygium aromaticum, L.) essential oil. Food chemistry, 276: 180-186.

Rathore, S., Desai, P. M., Liew, C. V., Chan, L. W., Heng, P. W. S. (2013). Microencapsulation of microbial cells. Journal of Food Engineering, 116: 369-381.

Saloko, S., Darmadji, P., Setiaji, B., Pranoto, Y. (2014). Antioxidative and antimicrobial activities of liquid smoke nanocapsules using chitosan and maltodextrin and its application on tuna fish preservation. Food Bioscience, 7: 71-79.

Sidira, M., Galanis, A., Nikolau, A., Kanellaki, M., Kourkoutas, Y. (2014b). Evaluation of Lactobacillus casei ATCC 393 protective effect against spoilage of probiotic dry-fermented sausages. Food Control, 42: 315-320.

Sidira, M., Kandylis, P., Kanellaki, M., Kourkoutas, Y. (2015). Effect of immobilized Lactobacillus casei on the evolution of flavor compounds in probiotic dry fermented sausages during ripening. Meat Science, 100: 41-51.

Sidira, M., Karapetsas, A., Galanis, A., Kanellaki, M., Kourkoutas, Y. (2014a). Effective survival of immobilized Lactobacillus casei during ripening and heat treatment of probiotic dry-fermented sausages and investigation of the microbial dynamics. Meat science, 96: 948-955.

Sjofjan, O., Adiansah, I., Sholiha, K. (2019, January). Effect of supplementation of either powdered or encapsulated probiotic on carcass percentage, giblets and small intestinal 
morphometric of local duck. In Journal of Physics: Conference Series (Vol. 1146, No. 1, p. 012039). IOP Publishing.

Song, M. Y., Van-Ba, H., Park, W. S., Yoo, J. Y., Kang, H. B., Kim, J. H., ... \& Ham, J. S. (2018). Quality Characteristics of Functional Fermented Sausages Added with Encapsulated Probiotic Bifidobacterium longum KACC 91563. Korean journal for food science of animal resources, 38: 981.

Triki, M., Herrero A.M., Rodríguez-Salas, L., Jiménez-Colmenero, F., Ruiz-Capillas, C. (2013). Chilled storage characteristics of low-fat, n-3 PUFA-enriched dry fermented sausage reformulated with a healthy oil combination stabilized in a konjac matrix. Food Control 31: 158-165.

Turhan, E. U., Erginkaya, Z., Polat, S., Ozer, E. A. (2017). Design of probiotic dry fermented sausage (sucuk) production with microencapsulated and free cells of Lactobacillus rhamnosus. Turkish Journal of Veterinary and Animal Sciences, 41: 598-603.
Wang, S. Y., Ho, Y. F., Chen, Y. P., Chen, M. J. (2015). Effects of a novel encapsulating technique on the temperature tolerance and anti-colitis activity of the probiotic bacterium Lactobacillus kefiranofaciens M1. Food Microbiology, 46: 494-500.

Warriss, P. D. (2010). Meat Science: An Introductory Text, CAB International Publishers, New York, NY, USA, 2010.

Wrona, M., Nerín, C., Alfonso, M. J., Caballero, M. Á. (2017). Antioxidant packaging with encapsulated green tea for fresh minced meat. Innovative Food Science \& Emerging Technologies, 41: 307-313.

Zain, N. A. M., Suhaimi, M. S., Idris, A. (2011). Development and modification of PVA-alginate as a suitable immobilization matrix. Process Biochemistry, 46: 2122-2129.

Zou, Y., Lee, H.-Y., Seo, Y.-C., Ahn, J. (2012). Enhanced antimicrobial activity of nisin-loaded liposomal nanoparticles against foodborne pathogens. Journal of Food Science, 77: 165-170. 